\title{
WACANA KEISLAMAN MINANGKABAU DI PERTENGAHAN ABAD KE-19: REFLEKSI SEBUAH NASKAH
}

\author{
Yerri S. Putra
}

\section{Pendahuluan}

Ada banyak pertanyaan yang muncul sesaat setelah kita membaca judul makalah ini. Pertama, tentang Islam dan perjuangan rakyat, apa hubungan Islam dengan perjuangan rakyat, baik itu Indonesia pada umumnya maupun Sumatra Barat pada khususnya, dalam perlawanannya mengusir penjajah. Kedua, tentu tentang dinamika pemikiran keislaman di Minangkabau di pertengahan abad XIX, bagaimana dinamika pemikiran keislaman di Minangkabau di abad tersebut? Dan apa pula hubungannya dengan perjuangan merebut kemerdekaan? Untuk itu, sebelum menjawab pertanyaan-pertanyaan tersebut secara keseluruhannya, terlebih dahulu, kita akan coba menguraikan permasalahan satu-persatu, hingga mendapat kejelasan. Namun demikian, yang perlu diperhatikan yaitu, studi ini tidak akan jauh-jauh dari objek yang dipilih, yakni Naskah Inilah Sejarah Ringkas Syekh Paseban Assyattari Rahimahullah Ta'ala Anhu (yang selanjutnya disingkat dengan SP), yang dikarang oleh Haji Imam Maulana Abdul Manaf Amin Al-Khatib.

Untuk Naskah SP sendiri, naskah Inilah Sejarah Ringkas Syekh Paseban Assyattari

Rahimahullah Ta'ala Anhu berukuran $14 \times 20 \mathrm{~cm}$, memiliki tebal 108 halaman. Naskah ini ditulis dengan tinta berwarna hitam dengan huruf Arab, dan Arab Melayu, sedangkan bahasa yang dipergunakan, ada tiga, yakni: Bahasa Arab, Bahasa Melayu dan Bahasa Minang. Bahasa Arab dipergunakan ketika penulis hendak mengemukakan ayat-ayat atau dalil-dalil dalam Islam, bahasa Melayu merupakan bahasa utamanya, dan bahasa Minang di dalam teks, sering dipergunakan ketika menuliskan dialog-dialog yang dilakukan antar tokoh. Jumlah baris dalam setiap halamannya rata-rata 16,7 dan panjang baris rata-ratanya $8,78 \mathrm{~cm}$. Jumlah kuras sebanyak 7 kuras, dan jumlah lembaran per kurannya adalah 8 lembar. Alas naskah berupa kertas berukuran folio, dan di setiap halamannya diberi blok teks yang berukuran 9,7 x 15,5 cm. Naskah ini terbilang baru, informasi yang terdapat di bagian kolofon, naskah ini selesai ditulis pada tanggal 19 Oktober 2001, dan tidak ada penjelasan kapan naskah ini mulai di tulis. Di halaman dua terdapat segi empat yang membentang membelah blok teks. Di dalam segi empat tersebut tertulis Untuk tanda / منسم الله الرحمن الرحيم / Bismillahirrahmannirahim dengan tulisan Arab baca, penulis menggunakan dua jenis tanda baca, yakni; tanda (.) untuk menandakan kalimat berhenti, dan pengganti peran tanda (,) untuk berhenti sejenak dan tanda (:) 
dipergunakan untuk mengahiri suatu kalimat, yang selanjutnya diikuti dengan kalimat dialog. Secara keseluruhannya, naskah ini mengandung tiga teks sekaligus, yang pertama, teks berisi ajaran-ajaran agama yang dianut oleh kelompok masyarakat Syattariyah. Kedua, teks sejarah kehidupan Syekh Paseban Assyattari Rahimahullah Ta'ala Anhu, dan ketiga teks pengalaman pengarang sendiri, baik itu ketika masih bersama Syekh Paseban, maupun sepeninggalnya. Naskah ini sekarang .tersimpan di Surau Nurul Huda, Batang Kabung, Koto Tangah, Tabing-Padang

Jika berbicara masalah perjuangan rakyat melawan kolonialisme di Indonesia, maka, tak lengkap rasanya apabila kita tidak menyimak proses lahirnya ideologi perlawanan, yang diusung dalam Islam. Mengapa demikian, Islam dan perjuangan kemerdekaan seakan lekat menjadi satu sejarah panjang, seperti yang diungkapkan oleh Azra dalam Bustaman-Ahmad (2002:12), bahwa Islam tidak hanya menyatukan masyarakat Indonesia dalam satu keagamaan, namun juga Islam telah mempererat basis ikatan sosial-keagamaan masyarakat Indonesia. Bisa dikatakan, dengan Islam perjuangan rakyat Indonesia yang semula bercorak kedaerahan menjadi lebur dalam satu solidaritas persaudaraan "saudara seagama (Islam)."

Islam masuk dan berkembang di wilayah Nusantara, termasuk Minangkabau ${ }^{1}$, membawa pemahaman dan ideologi yang beragam dengan jangka waktu yang berbeda pula. Di Minangkabau, berbagai sumber menyebutkan bahwa Islam mulamula masuk dan dikembangkan oleh Syekh Burhanuddin Ulakan, atau Burhân AlDîn atau Tuanku Ulakan (w. 1056-1104/1646-1692), yang baru pulang dari Aceh. Di Aceh, Syekh Burhân Al-Dîn berguru dengan seorang sufi dari persia bernama Syekh Abd. Al Ra'ûf Al-Sinkilî (w. 1024-1105/1615-1693). Di bawah ajaran Syekh Burhân Al-Dîn inilah Islam yang mula-mula terkonsentrasi hanya di seputar wilayah rantau Pariaman, kemudian meluas dan akhirnya dipeluk oleh sebagian besar penduduk Minangkabau. Navis (1980), mencatat perkembangan Islam dari satu ideologi ke Ideologi lainnya, memakan waktu kurang lebih limapuluh tahun. Namun, apabila kita melihat sumber-sumber lainnya, jarak antara masa Syekh Burhân Al-Dîn dengan masuknya ideologi keislaman yang Nakhsyabandiyah yakni selama 127 tahun $^{2}$.

Menarik disimak, bahwa Islam yang diajarkan oleh Syekh Abd. Al Ra'ûf AlSinkilî kepada murid-muridnya, termasuk Burhân Al-Dîn, di Minangkabau, sama sekali tidak membawa spirit perlawanan terhadap bangsa asing. Islam masuk dengan damai dan bersahabat, bahkan cenderung "dingin" dalam menyikapi permasalahan sekelilingnya. Dalam mengajarkan dan mengembangkan Islam, Al-Sinkilî tak lupa juga mensosialisasi azas-azas dan aturan-aturan yang berlaku dalam organisasi tarekat yang ia kreasikan, yakni Syattariyah. Syattariyah memang berkembang dengan pesat di Minangkabau, namun, di tempat lainnya di Indonesia,

1 Kawasan Minangkabau yang dimaksudkan di sini, yakni, meliputi sebagian besar wilayah Sumatera Barat saat ini kecuali Kep. Mentawai ditambah dengan wilayah Kampar, Hindra Giri Hulu (Riau), Semenanjung Malaya, Jambi dan wilayah pesisir Sumatera (termasuk pesisir Prop. Bengkulu). Agar hal ini tidak mengacaukan, maka di sini penulis menuliskan Minangkabau untuk mengatakan bahwa pengaruh konteks yang tersebut dirasakan ke seluruh kawasan alam Minangkabau, namun jika penulis menuliskan Sumatera Barat berarti konteks yang tersebut hanya meliputi wilayah Prop. Sumatera Barat.

2 Demikian menurut hitungan Oman Fathurahman, yang memulai hitungannya dari awal kedatangan Syekh Burhân Al-Dîn di tanah Minangkabau, dari Aceh. 
walaupun agak lambat, tarekat ini juga diajarkan, yang menurut dugaan banyak orang tarekat ini dibawa oleh murid-murid Al-Sinkilî yang lain, yang memang pada waktu itu tidak hanya memiliki seorang murid, Burhân Al-Dîn. ${ }^{3}$

Di masa itu juga, Islam berkembang dengan cepat. Kuat dugaan, tingginya minat orang Minang untuk memeluk agama Islam yang diajarkan oleh Burhân AlDîn di Ulakan karena unsur-unsur animisme dan mistik yang terkandung dalam ajarannya. Yatim (2002:202) mencatat bahwa para sufi Timur Tengah mendapatkan kemudahan dalam menyebarkan agama Islam, tidak saja di Minangkabau, namun juga di seluruh pelosok wilayah Nusantara dikarenakan adanya sinkronisasi antara kepercayaan Hindu yang dianut oleh penduduk pribumi dengan ajaran tasawuf yang dibawa oleh para sufi tersebut. Salah satu ajaran tasawuf yang kontroversial $^{4}$ yakni martabat tujuh. Dalam ajaran martabat tujuh disebutkan bahwa yang dimaksud wujud itu hanya satu walau kelihatannya banyak. Wujud yang satu itu memiliki dua dimensi yakni, dimensi batin (isi) dan dimensi lahir (kulit). Semua benda yang tampak adalah manifestasi dari dimensi batin, yaitu wujud yang hakiki, Allah S.W.T. Wujud yang hakiki itu mempunyai tujuh martabat, yakni 1). Ahadiyah, wujud hakiki Allah S.W.T., 2). Wahdah, hakikat Muhammad, 3). Wahidiyah, hakikat Adam, 4). Alam Arwah, hakikat nyawa, 5). Alam Mitsal, hakikat segala bentuk, 6). Alam Ajsam, hakikat tubuh, 7). Alam Insan, hakikat manusia. Kesemuanya bermuara pada yang satu, yakni Ahadiyah, Allah S.W.T., (Ibid: 302). Ajaran ini hanya salah satu bentuk aplikasi dari ajaran-ajaran tasawuf yang memang pada intinya mempersoalkan wujud Tuhan dan kaitannya dengan manusia juga hubungan tasawuf dengan syari' at.

Tasawuf, walau menjadi salah satu ajaran penting dalam tarekat Syattariyah, namun, tidakbanyakdariparapengikutnyadapatmemahamiajarantersebut. Bahkan, tak jarang banyak para pengikut ajaran tersebut keliru menginterpretasikannya. Akibatnya, sering terjadi benturan konseps antarsesama pengikut. Faturrahman (2002), mengatakan bahwa kesalahfahaman terhadap ajaran-ajaran tasawuf tersebut muncul dari bawah -orang awam- yang kesulitan memahami ajaran-ajaran tasawuf yang sangat filosofis, sehingga mereka menginterpretasikannya secara sederhana. Di kalangan para sufi sendiri, perbedaan interpretasi ajaran-ajaran tasawuf tersebut, diakui akan dapat mengganggu atau bahkan menyesatkan para murid. Dicurigai, doktrin-doktrin ajaran tasawuf tersebut diadaptasikan ke dalam tatanan sosial adat oleh para pemangku adat. Tujuan mereka melakukan hal tersebut mungkin untuk melegitimasikan dan juga mengkukuhkan kedudukan mereka dalam struktur adat di Minangkabau.

Azra (2004: 357), mengatakan bahwa para pengikut ajaran tasawuf itu membutuhkan waktu relatif lama untuk menguasai kemurnian ajaran tasawuf.

3 Azra (2004:256) menyebutkan bahwa sejak di Haramayn, Abd. Al Ra'ûf Al-Sinkilî, telah memiliki banyak murid. Murid-murid tersebut menyebar keseluruh pelosok bumi. Sayangnya, Azra tidak memiliki data pasti siapa murid-murid Al-Sinkilî di Haramayn tersebut. Di Indonesia, ia memiliki beberapa murid, seperti, Burhân Al-Dîn (Minangkabau), 'Abd. Al-Muhyi (Jawa Barat), 'Abd. Al-Mâlik b. Abd. Allâh (Semenanjung Malaya), dan yang paling terkenal yaitu, Dâwûd Al-Jâwî Al-Fansûrî b. 'Islâmîl b. Agha Mushthafâ b. Agha 'Alî Al-Rûmî (Aceh).

4 Dikatakan kontroversial, karena, bukan saja dari kalangan sufi non Syattariyah ajaran ini dipertentangkan, namun juga antar sufi yang sama-sama berasal dari tarekat Syattariyah tak jarang ajaran tasawuf ini diperdebatkan. 
Mereka dituntut untuk patuh secara penuh, lahir maupun batin, terhadap ajaran ortodoksi Islam, atau yang lebih tepat lagi kepada syari'at. Karena menurut para ulama tersebut, mustahil bagi para murid mencapai tujuan spritualnya tanpa mematuhi sepenuhnya doktrin ortodoks Islam. Akibatnya, para murid menjadi pasif karena mereka telah menarik diri ('uzlah) dari masalah duniawi untuk menguasai ajaran tasawuf. Akibat yang lebih buruk dari sikap pelarian diri (escapism) itu adalah kemunduran sosial ekonomi dan politik umat muslim. Secara religius (kemungkinan ini adalah implementasi dari bentuk interpretasi terhadap konsep ajaran tasawuf yang salah), ajaran ini dituduh sebagai sumber bid'ah dan takhayyul atau khurâfât. ${ }^{5}$

Kontroversi mengenai ajaran tasawuf tersebut di dalam teks SP, oleh pengarang, diceritakan perdebatan antara Syekh Paseban dengan Angku Calu yang membahas faham martabat tujuh.

/...di Batang Kabung yang dipanggilkan orang Angku Cupak karena beliau orang Cupak. Pengajian martabat tujuh itu sangat sulit difahaminya. Maka diminta oleh Marali gelar raja Mangkuto mengikut itu nama dan gelar orang Batang Kabung itu yang menjadi kepala orang muda Batang Kabung. Yang telah dimintanya kepada Angku Cupak bagaimana fahamnya, tetapi tidak mau terfaham olehnya. Oleh karena itulah dia datang ke Sungai Abang meminta faham martabat tujuh itu. Setelah dibaca oleh Angku Paseban beliau bertanya kepada Marali "Di mana diterimanya oleh Angku Cupak itu?” Dijawab oleh Marali “Di Calu Angku." Maka pada suatu hari pergilah Angku Paseban dengan tiga orang muridnya menemui Angku Calu di Muara Sijunjung. Tiba di Calu, waktu Maghrib telah masuk, maka beliau sembahyang saja di tepi air bersama murid yang bertiga itu. Sudah sembahyang Magrib, barulah beliau naik ke surau. Menjelang sampai di surau beliau berkata kepada murid yang bertiga itu kata beliau "Di atas surau nanti kita sama saja, tidak seperti guru dengan murid." Pagi-pagi beresoknya, orang sama minum. Beliau Angku Paseban minum sama pula Angku Calu. Maka bertanya Angku Calu "Dari mana?" Dijawab oleh Angku Paseban "Kami dari Lubuk Alung." Setelah selesai minum, ber [ceramah] ceramahlah Angku Calu dengan Angku Paseban // akhirnya sampai ceramah itu kepada persolaan martabat tujuh. Maka dibahaslah oleh Angku Paseban, maka terjadilah kekandasan .../ (AlKhatib.2001:21-22).

Selain dianjurkan mempelajari ajaran tasawuf, dalam Syattariyah, para murid juga diwajibkan mempelajari serta mentaati beberapa hal, yang bisa diartikan sebagai azas-azas yang mengikat para murid dalam menjalankan perintah guru dan setia dalam tarekat Syattariyah, seperti:

1. Melafazkan ussally dalam niat salat;

2. Wajib membaca basmallah dalam surat al-fatiúah;

3. Membaca doa qunut seraya mengangkat tangan pada salat subuh;

4. Menentukan awal bulan Ramadhan dan Idul Fitri melalui rukyat (melihat bulan);

5. Melaksanakan salat tarawih sebanyak 20 rakaat dan witir 3 rakaat di bulan Ramadhan;

5 Namun begitu, Azra tidak sependapat bahwa ajaran inilah yang membawa umat muslim kepada jalan kesesatan, karena kesesatan tersebut datangnya akibat dari salah interpretasi yang dilakukan pengikutnya. 
6. Mentalkinkan mayat;

7. Sunat menghadiahkan pahala bacaan bagi orang yang telah mati;

8. Ziarah kubur ke makam Nabi dan orang-orang saleh adalah sunat;

9. Merayakan maulid Nabi Muhammad Saw. pada bulan Rabiul Awwal dengan, antara lain, membaca Barjanzi;

10. Sunat berdiri saat membaca barjanzi (asyraqal);

11. Sunat menambah kata "wa bi úamdihi" setelah bacaan subúhana raby al'ala" ketika ruku' dan subúhana raby al-a'la ketika sujud;

12. Sunat menambahkan kata "sayyidina" sebelum menyebut nama Muhammad;

13. Memperingati kematian mayat (tahlil) hingga hari ketiga, ketujuh, dan keseratus;

14. Allah memiliki sifat, dan mempelajari sifat Allah yang 20 hukumnya wajib;

15. Wajib mengganti salat yang tertinggal, baik sengaja atau tidak sengaja;

16. Dianjurkan mempelajari tasawuf dan tarekat;

17. Sunat membaca zikir la ilaha illa Allah berjamaah setelah salat wajib;

18. Bertawasul ketika berdoa tidak termasuk perbuatan syirik;

19. Menyentuh al-Quran tanpa berwudlu hukumnya haram;

20. Wajib mencuci setiap barang yang disentuh anjing dengan tujuh kali siraman air dan salah satunya dengan tanah;

21. Bersentuhan kulit laki-laki dan perempuanyang bukan mahram membatalkan wudlu;

22. Orang yang sedang berhadas besar (junub) tidak sah mengerjakan salat malam sebelum mandi;

23. Azan pertama dalam sembahyang jumat hukumnya sunat;

24. Salat sunat sebelum salat jumat hukumnya sunat;

25. Menjatuhkan talak ketika istri sedang haid hukumnya sah;

26. Menulis ayat al-Quran dengan huruf latin hukumnya haram;

27. Surga dan neraka itu kekal keduanya;

28. Al-Quran itu bersifat qadim;

29. Alam bersifat baru;

30. Talak yang dijatuhkan tiga kali sekaligus berarti jatuh talak tiga. (Fathurahman. 2003: 260) ${ }^{6}$.

6 Informasi lain yang dituliskan Fathurahman dalam disertasinya (2003:261), mengenai identitas keberagamaan para penganut tarekat Syathariyyah di Sumatra Barat ini juga didefinisikan dengan apa yang mereka sebut sebagai "dua puluh satu amanah", yakni sejumlah ajaran dan ritual yang bersifat mengikat dan tidak boleh diubah. Materi tentang "dua puluh satu amanah" - yang memang tercantum dalam Anggaran Dasar dan Rumah Tangga Jamaah Syathariyyah Sumatra Barat - ini senantiasa disosialisasikan oleh guru-guru tarekat Syathariyyah dalam berbagai pengajiannya. Adapun kedua puluh satu amanah itu adalah sebagai berikut: (1). Puasa harus dengan melihat bulan (ru'yat al-hilal); (2). Salat tarawih 20 rakaat, ditambah witir 3 rakaat; (3). Membaca ussally dalam niat sembahyang; (4). Membaca basmalah pada surat al-Fatiúah dan permulaan surat dalam al-Quran; (5). Membaca doa qunut di waktu salat subuh; (6). Menentukan awal bulan dengan úisab taqwym, kecuali bulan Ramadan dan Idul Fitri, dengan melihat bulan; (7). Bermazhab kepada Imam SyAffi'y; (8). Beriktikad dengan iktikad ahlal-sunnah wa al-jama' ah; (9). Membaca wa bi úamdihi ketika ruku' dan sujud dalam salat; (10). Bertahlil dan berzikir; (11). Khutbah Jumat dengan hanya meng- 
Perihal hukum yang ke-8 yakni Ziarah kubur ke makam Nabi dan orang-orang saleh adalah sunat, tak heran apabila, makam-makam para ulama Syattariyah, termasuk makam Burhân Al-Dîn di Ulakan, sering diziarahi, terutama di bulan Syafar, pengikutnya ${ }^{7}$. Mengenai hal ini, setidaknya Al-Khatib menegaskan, beberapa kali dalam teks SP, pentingnya menghormati guru dan orang saleh. Fungsi dari ayatayat tersebut adalah sebagai alat atau pasal-pasal yang mengatur tata hubungan antara murid dengan gurunya, kewajiban murid mematuhi perintah guru sehingga nantinya terciptalah suatu sistem nilai kepatuhan murid terhadap gurunya -seperti yang telah dikatakan di atas- yang sedang dalam proses pemahaman ajaran-ajaran tasawuf.

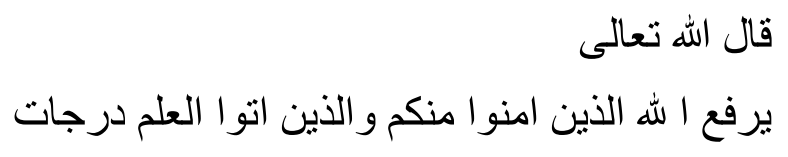

/...Artinya: Allah meninggikan segala orang yang beriman dan berilmu (ulama) akan beberapa derajat (pangkat)../(Al-Khatib. Op.Cit:2)

/...Nabi Muhammad dengan memuliakan ulama tersebut dalam haditsnya

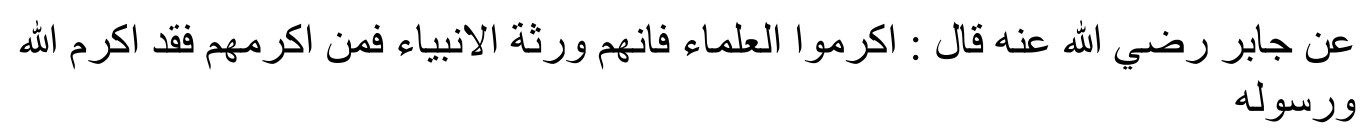

Artinya: Cerita dari Jabar Radhiallahu Anhu. Berkata ia, muliakan olehmu akan ulama, bahwa sungguhnya mereka adalah waris Nabi-Nabi, // Siapa yang memuliakan ulama [kan ulama] maka sungguhnya dia telah memuliakan Allah dan Rasulnya.

Satu hadits lagi menerangkan:

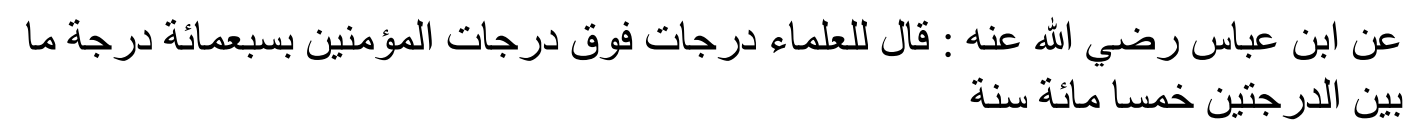

Artinya: Cerita dari Ibnu Abas Radiallahu Anhu. Ulama itu mempunyai kelebihan tujuh ratus derajat di atas derajat orang-orang yang mukmin yang jaraknya tiaptiap derajat lima ratus tahun.

gunakan bahasa Arab; (12). Berdoa (tahlyl) pada setiap kematian; (13). Mentalkinkan mayat; (14). Ziarah kubur ke makam para ulama dan orang saleh; (15). Bertarekat dengan tarekat Syathariyyah; (16). Baiat kepada guru tarekat; (17). Melakukan tawass' ul kepada guru pada saat berdoa; (18). Pergi bersafar ke Ulakan; (19). Memperingati maulid Nabi dengan membaca Syaraf al-Anâm; (20). Berdiri ketika sampai pada bacaan asyraqal dalam barjanzi; (21). Memakai kopiah di waktu sembahyang.

7 Mengenai ritual ini, Hamka (1950:24), mengomentari sebagai bentuk praktik-praktik kepercayaan yang aneh yang tidak ditemui dalil-dalil yang membenarkan melakukannya. Kegiatan berziarah ke makam guru, terutama sekali untuk kasus makam di Ulakan, tidak saja mendapat kritikan dari luar, namun juga kecaman dari murid-murid Ulakan sendiri. Hal ini dikarenakan, praktek-praktek tersebut sering dilakukan secara berlebihan (over acting), terutama di tingkat masyarakat awam, sehingga mengganggu ketentraman dan kekusyukan orang lain. 
Satu lagi hadits Nabi S.M yang menyatakan kelebihan ulama yaitu:

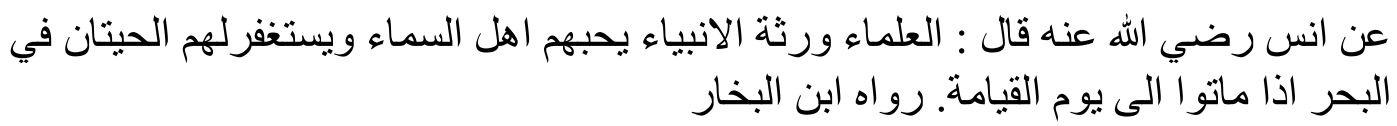

Artinya: Cerita dari pada Anas Radhiallahu Anhu. berkata dia, ulama itu pewaris Nabi, mengasihi akan mereka ahli langit dan memintakan ampun akan mereka ikan dalam laut apabila mereka-mereka mati hingga hari kiamat. Merawikan Ibnu Nizar.

Dengan tiga hadits ini dapatlah kita pemandangan, pengajaran bahwa Nabi menyuruh menghormati dan memuliakan ulama karena memuliakan ulama // itu kata Nabi sama dengan memuliakan Allah dan Rasulnya. Sehingga, kata Nabi, tujuh ratus kelebihan derajat ulama, dari derajat orang mukmin dan seluruh penghuni langit. Juga kasih dan menghormati ulama ikan dalam laut. Juga meminta ampunkan apabila mereka mati sampai hari kiamat.

Satu hadits lagi yang menerangkan kelebihan ulama. Nabi bersabda:

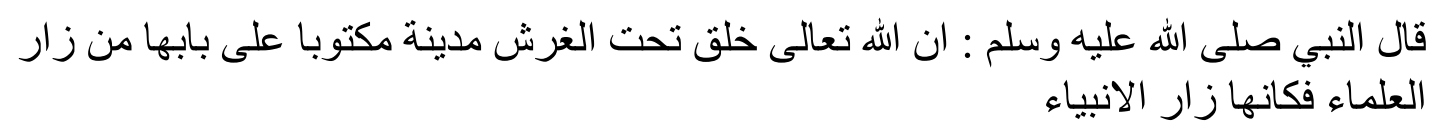

Artinya: Berkata Nabi S.M., bahwa sungguhnya Allah telah menjadikan sebuah kota di bawah "Arasy yang tertulis di atas pintunya, "Siapa yang mendatangi ulama, maka pahalanya telah sama dengan mendatangi Nabi-Nabi." Begitulah mulia dan terhormatnya ulama di sisi Allah dan Rasulnya. Orang-orang yang memandang leceh ulama akan mendapat azab Allah Subhanahu Wataala.../ (ibid:105-107).

\section{Masuknya Ideologi Baru}

Pada fase berikutnya, Islam di Minangkabau berkembang ke arah yang lebih longgar, bahkan juga radikal, namun masih mengandalkan organisasi tarekat sebagai media penyebarannya. Salah satu tarekat yang sedikit modern tersebut yakni Nakhsyabandiyah, yang diperkenalkan di awal abad XIX.

Seperti yang telah disebutkan di atas, bahwa dari sumber-sumber yang ada, ajaran-ajaran Nakhsyabandiyah masuk dan berkembang setelah 127 tahun lamanya ajaran Islam yang dikembangkan oleh tarekat Syattariyah dianut oleh sebagian besar penduduk Minangkabau. Dalam kurun waktu yang tidak sebentar itu, bisa dibayangkan, sulitnya bagi para "sufi modern" untuk mengembangkan ajaran ini. Bahkan tak jarang, akibat perbenturan ideologi, terjadi konflik, yang tidak sebatas 
perang mulut, namun juga perang fisik, antara para ulama Syattariyah dengan para "sufi modern" tadi.

Di awal abad XIX tersebut, ketegangan-ketengan antara dua penganut faham yang berbeda ini tak terhindarkan lagi. Bahkan, pertentangan-pertentangan tersebut, selajutnya, menjadi faktor penyebab munculnya konflik sosial di Minangkabau. Pertentangan atau konflik antara dua penganut faham yang berbeda tersebut di kenal dengan Istilah, pertentangan antara kaum Tua dan Kaum Muda. Namun begitu, menyangkut ketegangan tersebut, beberapa sumber mengatakan bahwa pangkal balanya bukanlah menyangkut persoalan perbedaan faham dan ajaran saja, melainkan yang utama yakni saling rebutan kehormatan dan pengikut. Syekh Jalaluddin, seorang ulama di Cangkiang misalnya, telah berhasil mendapatkan simpati dari para pengikut tarekat Syattariayah, hingga mereka sudi berpindah ke Nakhsyabandiyah. Hal tersebut, tentu saja membakar emosi para ulama atau guruguru Syattariyah ${ }^{8}$ (Fathurahman. Op. Cit: 229).

Di antara persoalan yang sering menjadi perdebatan antara tarekat Naqsybandiyyah dengan Syathariyyah adalah menyangkut penetapan awal dan akhir Ramadhan. Saat ini, terutama di sekitar Padang Panjang dan di Pariaman, perbedaan tersebut masih juga terjadi. Biasanya, para penganut Syathariyyah merayakan puasa Ramadan dua hari kemudian setelah para penganut tarekat Naqsybandiyyah merayakannya, sehingga karenanya mereka mendapatkan julukan "orang puasa kemudian", sementara tarekat Naqsybandiyyah disebut orang sebagai "orang puasa dahulu". 9

/... Maka pada tahun 1918 Masehi, duduklah memerintah di Koto Tangah, Menteri Abas, orang Maninjau. Menteri di masa dahulu yang sekarang adalah Camat namanya. Setelah datang bulan Ramadhan (bulan puasa) / / dia tercengang, sebab Koto Tangah belum puasa, sedangkan dia telah puasa, yang orang Koto Tangah melihat bulan dahulu baru masuk puasa, kalau sudah kelihatan bulan di malam tiga puluh Sya'ban maka baru siangnya mulailah puasa. Kalau tidak kelihatan bulan di malam tiga puluh Sya'ban maka disempurnakan bilangan Sya'ban tiga puluh hari, lalu besoknya puasa. Melihat hal itu, perasaan Menteri Abas tidak enak sebab ke mana dia sembahyang Tarwih, sebab orang belum Tarwih. Begitu pula berhari raya, dia sudah berlepas orang masih puasa, ke mana dia sembahyang hari raya, orang masih puasa. Gurunya adalah Haji Abdul Karim Amirullah (Inyik Rasul), ayah oleh buya Hamka.../(Al-Khatib. Op.Cit: 24-25)

/.....Maka diundangnya Syekh Paseban ke kantornya menghadiri pertemuan itu. Dalam pertemuan itu, mula pertama memberi pengajian Inyiak Rasul. Dalam

8 Lebih jauh lagi Fathurahman (2003), menyebutkan bahwa, selain rebutan popularitas, tentu saja, persoalan yang menyangkut perbedaan faham dan ajaran juga menjadi salah satu pemicu terjadinya ketegangan tersebut. Inı pun dengan catatan bahwa, hal yang dipertentangkan itu bukan menyangkut doktrin-doktrin tasawuf itu sendiri, melainkan lebih berorientasi pada aspek syariat. Para pengikut tarekat Naqsybandiyyah memang dikabarkan tidak menyukai ajaran martabat tujuh, sebuah ajaran tentang teori penciptaan alam yang bersumber dari kitab al-Tuúfah al-Mursalah ila R'ú al-Nabi karangan al-Burhanra'ry, dan dikembangkan oleh Abdurrauf al-Sinkili, serta dielaborasi untuk menjelaskan dan menginterpretasi doktrin waúdat al-wuj'd yang pernah menghebohkan di Dunia Melayu-Indonesia itu. Persoalannya, penting dicatat bahwa dalam konteks Sumatra Barat, ajaran waúdat al-wuj'd itu sendiri ternyata tidak diteruskan dan dikembangkan oleh para pengikutnya, sehingga, sejauh berkaitan dengan ajaran waúdat al-wuj'd ini, corak tarekat Syathariyyah di Sumatra Barat menjadi relatif berbeda dengan corak tarekat Syathariyyah yang dikembangkan, misalnya, oleh al-Sinkili di Aceh (Dobbin 1992: 144), kendati dalam beberapa hal lain, seperti menyangkut ritual zikir atau penekanan pada aspek syariat, tidak ada perbedaan yang terlalu tajam di antara keduanya.

9 Schrieke 1973: 26; lihat juga Suryadi 2001: 96. 
pengajian itu akhirnya sampai ke soal puasa "Yang kita sayangkan di masa sekarang zaman telah maju tetapi sebahagian kita masih suka juga di zaman bodoh. Apa sebabnya? Kalau dahulu kita akan masuk puasa tilik dahulu bulan, kalau sudah tampak baru kita puasa. Melihat bulan itu ke tempat yang tinggi, ke atas bukit, itu pekerjaan berbahaya mendatangkan penyakit. Mana contohnya? Kita pergi ke atas bukit di situ tidak ada dangau tempat berteduh. Dalam kita menanti-nanti bulan, ada badai gadang dan hujan, kita dangau tidak ada, terpaksalah basah kuyub tiba di rumah bangkit Kuro. Padahal sekarang telah ada almanak, telah tentu satu Ramadhan tidak mendaki bukit dan tidak berhujan-hujan dan tidak kedinginan. Tidaklah bodoh namanya itu yang mudah sudah ada kita pakai juga yang sukar lagi berbahaya."

Maka mengusul Syekh Paseban kata beliau "itu keterangan tuanku betul. Ya, masih bodoh juga sebahagian kami betul itu. Berbahaya pergi melihat bulan itu ke tempat yang tinggi ke atas bukit, tempat yang sunyi tidak ada dangau, kalau tiba badai dan hujan lebat ya bangkai dingin dibuatnya. Maka mendengar keterangan tuanku ingin pula hati kami kepada yang mudah itu. Tetapi sebelum kami pindah kepada yang mudah itu kami ingin dahulu mendengar hadits Nabi Muhammad yang menyuruh memasuki puasa dengan melihat hisab." Mendengar usul dari Syekh Paseban itu maka Inyiak Rasul terdiam sebab tidak ada haditsnya yang menyuruh memasuki puasa dengan melihat hisab.../ (Ibid: 26-27).

Demikianlah, bagi sufi-sufi yang membawa ajaran baru, memang tak mudah mensosialisasikan ajaran tersebut di kampung halamannya. Usaha pemurnian ajaran Islam oleh para sufi tersebut selalu mendapatkan kegagalan, karena faham keslaman aliran Syattariyah yang telah dianut selama berpuluh-puluh tahun oleh sebagian besar masyarakat muslim di Sumatera Barat, bahkan telah menjadi semacam identitas diri bagi masyarakat muslim itu. Apabila ajaran-ajaran baru yang dikembangkan tidak diterima oleh masyarakatnya, bisa-bisa mereka dihukum di buang dari Nagari asalnya, seperti yang di alami oleh Syekh Daûd Al-Sûnur (Suryadi. 2004:180), juga yang pernah di alamai oleh tiga haji, yakni Haji Miskin, Haji Piobang dan Haji Sumanik (1803), yang baru pulang dari Mekkah, dan hendak menyebarkan doktrin-doktrin ajaran Wahabiyah dengan segala bentuk larangannya kepada orang kampungnya, mendapat pertentangan yang keras dari kekuatan ordonansi Syattariyah, mereka dipermalukan oleh guru-guru tarekat Syattariyah dan akhirnya masing-masingnya memutuskan untuk pergi meninggalkan kampung halamannya.

Puncak serangkaian pertengkaran tersebut terjadi di pertengahan abad XIX, ketika ketiga orang haji tersebut bertemu dengan sosok Tuanku Nan Renceh ${ }^{10}$ (Luhak Agam Kamang), seorang yang radikal. Dari situ meletuslah perang panjang, yang dikenal dengan Pemberontakan Paderi (w. 1821-1830).

Amran (1980:386), mengatakan bahwa pemberontakan Paderi ini adalah puncak dari rangkaian perdebatan mengenai benar dan salah, halal dan haram

10 Dari sini, Amran sendiri tidak menjelaskan siapa yang bertemu dengan Tuanku Nan Renceh, apakah salah satu, dan kemudian yang lainnya menyusul, bertemu Tuanku Nan Renceh, ataukah mereka bersepakat bersama bertemu dengan Tuanku Nan Renceh. Tuanku Nan Renceh sendiri, menurut beberapa informasi yang diberikan oleh Suryadi (2003), adalah merupakan salah seorang dari kelompok radikal yang terkenal dengan julukan Tuanku Nan Salapan; Tuanku Nan Renceh, Tuanku di Kubu Sanang, Tuanku di Kota Hambalau, Tuanku di Padang Lawas, Tuanku di Padang Luar, Tuanku di Galuang, Tuanku di Lubuak Haur, dan Tuanku di Bansa. Munkin saja para haji itu, secara terpisah, bertemu dengan masing-masing dari kelompok Tuanku Nan Salapan. 
dalam ajaran Islam yang berkembang sebelumnya. Kaum Paderi beranggapan bahwa Islam yang dianut oleh masyarakat sebelumnya, atau populer dengan sebutan kaum tua, penuh dengan unsur-unsur animisme, mistik, takhayyul, bid'ah dan khurâfât"11. "...gerakan Pidari ini dikembangkan oleh orang-orang yang penuh cita-cita, bersedia berkorban, penuh dinamisme. Tetapi kemudian sering dipaksakan secara berlebih-lebihan, terlalu picik dan kolot, kadang-kadang sama sekali tidak ada lagi hubungannya dengan agama yang ingin mereka "murnikan" sendiri. Bahwa mereka menentang adat istiadat yang bertentangan dengan agama, kita mengerti sekali..."12. Akhirnya, perang panjang tersebut dapat terselesaikan, itupun setelah adanya campur tangan dari pihak ketiga, yakni Belanda. Namun, akibat campur tangan yang dinilai berlebihan dari Belanda, umat muslim di Minangkabau menjadi bertambah benci kepada bangsa asing, dan mempertebal keyakinan mereka untuk bersatu dalam mengusir bangsa Yahudi, bangsa Kafir ${ }^{13}$ dari tanah Negerinya.

Sedangkan menurut pengarang naskah sendiri, kelompok Wahabi tersebut telah juga menyebarkan ajaran-ajaran yang tidak ada dasar hukumnya dalam Islam. Beberapa bentuk larangan yang dikembangkan oleh kelompok Wahabi adalah, seperti yang tertulis dalam naskah SP:

/...Muhammad Abdul Wahab pendiri mazhab Wahabi memerintahkan pengikutnya yang dibantu oleh laskar Ibnu Sa'ud adalah:

(Pertama). Sekalian rakyat dilarang keras merokok karena merokok itu katanya haram, pekerjaan syetan sebab tembakau berasal dari kejamban syetan.

(Kedua). Tidak boleh atau dilarang melagukan azan sebab kaum // Wahabi menaklukkan Mekkah di atas ketujuh menara Al-Haram Bilal. Melakukan azan dengan suara yang merdu.

(ketiga). Tidak boleh membunyikan radio karmofon, kalau dapat ditangkap dihancurkan semuanya.../ (Al-Khatib. Op.cit. 94-95).

Berbagai sumber mempercayai bahwa dinamika kehidupan sosial-politik umat muslim di Sumatra Barat khusunya, dan Nusantara umumnya, tak terlepas dari dinamika kehidupan sosial-politis yang sering terjadi di Mekkah khususnya, dan dunia Arab umumnya. Hal tersebut dikarenakan, wilayah Arab telah sejak lama

11 Takhayyul ialah adanya kekuatan ruh yang mampu mempengaruhi pikkiran dan jasad manusia, kekutan itu dapat menyakiti dan menyembuhkan. Umpamanya, perdukunan, ramalan, mantra termasuk mencampur adukan antara adat istiadat dan agama yang bertentangan dengan agama Islam. Sedangkan Khurâfât adalah perbuatan syirik tetapi menamakan atas ajaran agama Islam. Contoh: percaya kepada jimat yang bertuliskan ayat Al-Quran yang digabung dengan mantra adat, adanya kekuatan benda yang dikeramati. Seperti: keris, tombak, kuburan, dll. Ziarah kubur yang berlebih-lebihan, minta tolong agar terlepas dari sesuatu kesukaran, seperti: minta rezki, minta jodoh, minta kedudukan,dll.

12 Beberapa pemikiran yang kontroversial yang dikembangkan Paderi ini, menurut catatan Amran, seperti, memaksakan kepada pemeluk Islam di Minangkabau untuk berpakaian ala orang Arab, yang biasa hidup di Padang Pasir, agar menjadi umat Islam tulen pikirnya. Yang lain, cara berjalan bagi wanita, tata cara menatap sesuatu, tentang brewok, candu, serta menghilangkan unsur-unsur sutra yang digunakan dalam perlengkapan adat serta baju perangkat adat.

13 Sebenarnya, sebelum Pemberontakan Paderi inipun, masyarakat Minang, yang juga dimotori oleh ulama-ulama Syattariyah, pernah juga melakukan perperangan melawan Belanda, sebut saja misalnya, perang di Koto Tangah, di Pauh, yang keduanya juga sangat terkenal. Perperangan-perperangan itu pada dasarnya dilatarberakangi oleh praktik-praktik politik yang diterapkan Belanda di Minangkabau, yang bagi orang Minang sangat kontroversial karena telah menghapuskan hak orang Minang dari tanah Negerinya sendiri. Seperti diberlakukannya pajak (balesting) atas tanah dan penghasilan, serta rodi. 
menjadi kiblat umat Muslim di seluruh pelosok kawasan di dunia. Setiap tahunnya, ratusan bahkan ribuan umat muslim dari seluruh pelosok dunia, termasuk dari Sumatra Barat, pergi ke Mekkah untuk menunaikan ibadah haji. Perlu dicatatat, bahwa kepergian umat muslim ke Mekkah tersebut bukan semata-mata untuk menunaikan ibadah haji, selain itu, diantara mereka juga berniat memperdalam ilmu dan pemahaman mereka tantang agama Islam, berguru kepada guru-guru agama yang ada di Negeri Arab, terutama menyangkut masalah-masalah Figh, Nahwu dan Syaraf. Hal yang sangat berbeda tentunya jika kita membandingkan dengan kondisi saat ini. Perbedaan lainnya yang paling mendasar ialah menyangkut status sosial mereka yang pergi haji, rata-rata mereka, terutama yang berasal dari Sumatra Barat adalah guru-guru agama di daerahnya masing-masing ${ }^{14}$.

Terlebih lagi sejak dibukanya Terusan Suez tahun 1869. Koneksi terhadap Negeri-Negeri Arab terasa semakin dekat, setidaknya, sejak saat itu, ada saja orang Minang yang pergi ke Mekkah, lalu pulang dengan membawa ideologi keislaman yang diperolehnya di Mekkah, untuk nantinya dikembangkan di kampung halamannya (Suminto. 1986).

Di Arab, setidaknya, semenjak kemunduran Dinasti Ûsmâni ${ }^{15}$ (Turki), terjadi berbagai ketegangan. Di masa itu, Ibn 'Abd Al-Wahhab ${ }^{16}$ murid dari 'Abd Allah bi Ibrahim bi Sayf Al-Najdi Al-Madani, seorang ulama Naksyabandiyah, mendeklarasikan perang terhadap doktrin-doktrin tradisional yang dianggap mengandung ajaran-ajaran sesat dan telah membawa kemunduruan sosial ekonomi dan politis umat Islam. Alasan tersebut cukup kuat, mengingat bangsa Eropa telah memulai mengembangkan ilmu pengetahuan dan tekhnologinya kembali, bahkan beberapa diantaranya, seperti Inggris, Belanda, Prancis dan Spanyol telah melakukan ekspansi ke wilayah-wilayah di luar Eropa, termasuk Asia Tenggara, juga Sumatra Barat. Ketegangan-ketegangan tersebut selanjutnya melahirkan perperangan, perebutan kekuasaan, setelah gerakan 'Ibn Abd Al-Wahhab bergabung dengan kekuatan Raja Ibn Sa'ud menjatuhkan rezim Raja Syarif Husen dan akhirnya menguasai seluruh Jazirah Arab (Ali. 2003). Di bawah kekuasaan Raja Ibn Sa'ud inilah faham Wahabiyah dapat berkembang dengan cepat ke penjuru negeri Islam, termasuk Sumatera Barat. Sebaliknya, faham Syafi'i mulai melemah karena banyaknya ulama-ulama tua menyembunyikan diri ke daerah pedalaman Arab.

Di Sumatera Barat, pengikut faham pembaharuan Islam itu juga mulai meningkat jumlahnya, hal tersebut dikarenakan sebagian besar masyarakat semakin simpati terhadap gerakan perjuangan yang didengungkan oleh orangorang Islam modern, namun perlu dicatat juga bahwa pada masa itu juga, kekuatan

14 Bagi orang Minang, terutama mereka kaum reformis Islam, Dalam makalahnya Suryadi (2001: dan 2003), mereka, kaum reformis Islam, yang gagal dalam gerakan pemurnian ajaran Islam di kampun halamannya, sering kali kembali merantau ke Mekkah untuk lebih memperdalam ilmu keagamaannya, setelah itu mereka pulang dan kembali meyebarkan faham Islam di kampung halaman mereka.

15 Tentang pengaruh dan kekuasaan kerajaan Usmani ini selengkapnya lihat DR. Badri Yatim. 2002. Sejarah Peradaban Islam. Jakarta: PT. RajaGrafindo Persada. Lihat juga Prof. K. Ali. 2003. Sejarah Islam: Tarikh Pramodern. Jakarta: PT. RajaGrafindo Persada.

16 Azra (2004:135), memberikan catatan khusus mengenai Ibn 'Abd Al-Wahhab, walaupun gurunya termasuk salah satu kelompok tradisionalis (Nakhsabandi), yang akan diperanginya, namun, pemikirannya lebih banyak dipengaruhi oleh Muhammad Hayat, seorang muhaddits dengan reputasi yang lumayan di Haramayn. 
Islam Syattariyah pun mulai berkurang, seiring dengan wafatnya ulama-ulama Syattariyah yang dahulu sangat berpengaruh. Sedikit demi sedikit, pengaruh Islam Syattariyah itu pun melemah, tuduhan-tuduhan bahkan ejekan diberikan kepada mereka yang masih menganutnya.

Di daerah lain, di luar Sumatra Barat, gerakan-gerakan perjuangan yang dipelopori oleh ulama kaum muda, melahirkan bentuk gerakan yang lebih modern dan teroganisir. Mereka dengan kesadaran persatuan dan kesatuannya, membentuk organisasi-organisasi politik sosial dan masyarakat, seperti Sarekat Dagang Islam (1909), Muhammadiyah (1920), Nahdlatul Ulama (1926), Persatuan Tarbiyah Islamiyah (1930), dan juga dalam bentuk partai politik seperti, Persatuan Muslimin Indonesia (1932), Sarekat Islam (pecahan dari SDI), Partai Komunis Indonesia (juga pecahan SDI), Partai Islam Indonesia (PII. 1938).

\section{Menulis Untuk Mengingat dan Menghormati Guru}

Sangat menarik membaca Naskah Inilah Sejarah Ringkas Syekh Paseban Assyattari Rahimahullah Ta'ala Anhu tersebut. Pembaca seolah dibawa pada konteks kehidupan sosial masyarakat Minangkabau yang berlaku di pertengahan abad ke XIX, zaman di mana awal dari bentuk-bentuk perjuangan yang lebih teroganisir dan modern, awal terbentuknya organisasi-organisasi politik di Indonesia.

Imam Maulana Abdul Manaf Amin Al-Khatib sendiri, dilihat dari usianya, adalah saksi nyata dari pergolakan umat muslim melawan penjajahan. Usianya kini telah mencapai 83 tahun (8 Agustus 1922), namun, ingatannya masih cukup tajam untuk mengingat kembali momen-momen masa lalu, terutama kenangan terhadap guru-gurunya. Ia, bersuku Balai Mansiang, dilahirkan di Batang Kabung, Tabing, Padang, dari pasangan Amin dan Fatimah.

Di usia yang beranjak dewasa, ia, oleh dorongan keluarganya, dituntut untuk dapat menguasai ilmu agama. Untuk itu, dalam usia yang baru delapan tahun, ia telah belajar mengaji kepada seorang guru perempuan bernama Sari Makah di Muaro Panjalinan. Selepas dari Muaro Panjalinan, beliau pindah ke Batang Kabung guna mendalami Qira'at kepada Angku Fakih Lutan ${ }^{17}$. Mengenai pendidikan formal, di tahun 1930, ia mulai bersekolah di Sekolah Desa di Muaro Panjalinan, selepas dari situ, dilanjutkannya ke pendidikan Gubernemen di Tabing. Di tahun 1936, Imam Maulanan memutuskan untuk pergi berguru memperdalam pemahaman agama dan mendalami kitab gundul kepada Syekh Paseban di Koto Panjang.

Bersama Syekh Paseban ${ }^{18}$ inilah, ia banyak memperoleh pengetahuan, terutama sekali pada kegiatan menulis dan menyalin naskah. Sepeninggal Syekh Paseban (1937), ia pindah ke Batagak-Bukittinggi, dan berguru kepada Syekh Haji Ibrahim. Akhirnya, di tahun 1940, ia memutuskan untuk tidak lagi menuntut ilmu agama, melainkan mengembangkan ilmu-ilmu kreatif, di bidang kepenulisan, dan wawasannya melalui membaca. Sekarang, beliau memimpin surau Nurul Huda di

17 Fakih Lutan sendiri sebenarnya teman sepermainan Imam Maulana, karena jarak usia mereka pada waktu itu tidak berbeda jauh, namun, karena Fakih Lutan merupakan Khalifah Syekh

Paseban, maka posisinya pada waktu itu adalah telah menjadi seorang guru agama.

18 Dengan Syekh Paseban inilah Imam Maulana diterima bai' at dan talkin zikirnya terhadap tarekat Syattariah. 
Batang Kabung, Tabing, Padang.

Amir (2002), memastikan bahwa Haji Imam Maulana juga memiliki jaringanjaringan yang erat antarsesama pengikut tarekat Syattariyah yang ada di Sumatera Barat. Hal ini dapat dilihat dari aktivitasnya mengikuti kegiatan-kegiatan keagamaan secara periodik di surau-surau Syattariyah, seperti Kampung Kalawi, Pauh, dan di Lubuk Lintah. Aktivitas keagamaan itu beliau lakukan sebagai upaya mengaktifkan jaringan-jaringan Syattariyah. Beliau juga memiliki jemaah yang tidak sedikit yang berasal dari dalam maupun juga luar Sumatera Barat.

Kemampuan beliau menulis dan menyalin naskah menggunakan tulisan Jawi dan Arab cukup besar. Kabarnya, beliau sanggup menyelesaikan satu naskah hanya dalam kurun waktu enam bulan ${ }^{19}$. Aktivitas penulisan tersebut beliau lakukan di surau, baik itu surau Nurul Huda maupun surau Paseban. Naskah-naskah beliau tersebut antara lain:

1. Risalah Mau'izatul Hasanah;

2. Fadilatus Syuhur Jilid I: Menerangkan keutamaan bulan, dan sejarah maulid;

3. Fadilatus Syuhur Jilid II: Menerangkan kelebihan bulan Muharam dan kelebihan Asyura;

4. Fadilatus Syuhur: Menerangkan penetapan bulan Ramadhan, kelebihan ibadah-ibadah di dalamnya dan juga kelebihan bulan Syawal;

5. Inilah Sejarah Ringkas Aulia Allah Ashalihin Syekh Burhanuddin Ulakan yang Menyebarkan Agama Islam di Daerah Minangkabau ini;

6. Inilah Sejarah Ringkas Syekh Paseban Assyattari Rahimahullah Ta'ala Anhu;

7. Sejarah Ringkas Auliah Allah Asshalihin Syekh Abdurrauf (Syekh Kuala);

8. Kitab Mi'raj Nabi Muhammad;

9. Sejarah Ringkas Syekh Muhammad Natsir (Syekh Surau Baru);

10. Kitab Al-Taqwim;

11. Risalah Shobilatul Rishad;

12. Sejarah Al-Husain Rasulullah Shalallahu Alaihi Wassalam;

13. Kitab Riwayat Hidup Iaman Maulana Abdul Manaf Amin Al-Khatib;

14. Kitab Menerangkan Perkembangan Agama Islam di Minangkabau Semenjak

Dahulu Dari Syekh Burhanuddin Ulakan Sampai ke Zaman Kita Sekarang;

15. Risalah Mizan Al-Qulub;

16. Kitab Tahqiq (Tasawuf).

Aktivitas penulisan dan penyalinan naskah beraksara Arab maupun juga Jawi, menurut Adriyetti Amir dilakukan oleh ulama-ulama di surau mereka. Hal ini bertujuan untuk memudahkan murid-murid mereka mempelajari ajaran-ajaran yang diberikan, selanjutnya murid-murid itu menyalin kitab-kitab guru untuk dimiliki, yang pada akhirnya ajaran-ajaran tersebut dapat pula diturunkan kepada 19 Menurut keterangan beliau, hal ini pernah beliau lakukan ketika salah seorang peneliti datang mengunjungi beliau dan meminta sebuah naskah mengenai riwayat hidup beliau. Namun, sampai saat itu beliau belum pernah sekalipun beliau menulis riwayat hidupnya sendiri, sehingga beliau meminta waktu kepada si peneliti untuk selama enam bulan. Enam bulan kemudian naskah tersebut selesai beliau tulis. 
murid-murid mereka nantinya (Amir. Loc.Cit.).

Bagi Imam Maulana sendiri, alasan penting untuk menulis naskah, terutama naskah-naskah yang bercerita tentang guru-guru dan ulama-ulama, adalah sebagai tanda penghormatannya terhadap jasa-jasa yang telah diberikan oleh guru-guru dan ulama-ulama tersebut, selain memang, naskah tersebut merupakan pesanan dari beberapa orang, yang secara khusus, maupun tidak mengunjunginya dan naskah ataupun juga meminta ia menuliskan sebuah naskah. Alasan-alasan, kenapa ia menulis kitab, sering ia tuliskan dalam naskah-naskahnya, seperti dalam naskah SP.

/...Berkehendak sebahagian penduduk Koto Tangah supaya saya dapat menyusun sejarah beliau "Syekh Paseban", karena kami -kata mereka- hendak tahu dengan sejarah beliau, karena beliau seorang ulama besar yang masyhur di MK (Minangkabau) yang menganut mazhab Syafi'i Radhiallahu Anhu dan penganut tarekat Syattari.../ (Al-Khatib. Op.cit: 10).

/...(Kedua) Saya bertemu hadits nabi dalam kitab Arsyad Al Abad yang berbunyi:

$$
\text { ملوسا مركا دقف مكروكا نمف عايبنالا ةثرو مناف عاملعلا اومركا : للقاق منع ملا يضر رباج نع }
$$

Artinya: Ceritera dari pada Jabar Radhiallah Anhu. Berkata ia “Muliakan olehmu akan ulama karena mereka adalah sebagai pewaris nabi-nabi. Maka siapa yang memuliakan mereka, maka telah berarti memuliakan Allah dan Rasullnya."

Satu lagi hadits nabi yang berbunyi yaitu:

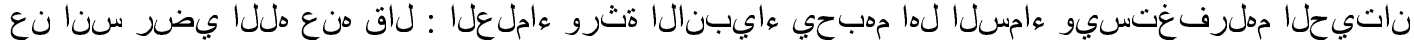

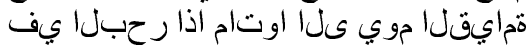

Artinya: Ceritera dari pada Anas Radhiallah 'Anhu. Berkata Nabi S.M, "ulama itu adalah mewaris nabi, mengasihi akan mereka ahli langit dan minta ampunkan bagi mereka ikan dalam laut. Meminta ampunkan apabila mereka mati hingga hari kiamat.../ (Ibid: 11).

\section{Syekh Paseban: Ulama yang Kharismatik Pada Abad Perubahan}

Syekh Paseban, lahir di Kampung Koto Panjang, Koto Tangah, Padang, tahun 1234 Hijriah (1817 Masehi). Nama kecil beliau adalah Karaping, gelar Sidi Alim, suku beliau Piliang. Setelah beranjak dewasa, beliau diantar oleh kedua orang tua beliau untuk belajar mengaji ke Tanjung Medan, Ulakan. Adalah Syekh Habibullah (khalifah keenam dari Syekh Burhanuddin Ulakan) yang menjadi ulama di Tanjung Medan pada waktu itu. Dengan Syekh Habibullah beliau menekuni bidang Quranulkarim. Namun walaupun telah tiga kali menamatkan Qur'an, beliau tidak mampu memahami dan menghafalkan Al-Qur'an. Oleh karena mendapat kesulitan dalam memahami pelajaran yang diberikan oleh guru, ia memutuskan untuk kembali ke kampung halamannya. Di kampung beliau menjadi preman, bergaul dengan guru-guru silat. 
Beberapa lama kemudian, akhirnya ia berniat lagi untuk mempelajari ilmu agama. Untuk itu, ia pergi ke Malalak (w. 1356 H/1837) dan berguru dengan Angku Syekh Malalak Limo Puluah. Setahun belajar di Malalak, ia tetap mendapatkan kesulitan dalam memahami pelajaran, atas dasar itu pula, sang guru, Angku Syekh Malalak Limo Puluah, mengambil kebijaksanaan untuk memindahkannya ke Pakandangan, berguru kepada Syekh Surau Gadang Pakandangan. Di Pakandangan inilah, ia akhirnya mampu memahami dan menguasai ajaran-ajaran Islam yang diberikan oleh sang guru. Sesuatu yang tak lazim memang, karena di Pakandangan ini, ia hanya membutuhkan waktu selama tiga bulan untuk pada akhirnya dapat menguasai seluruh ajaran yang diberikan Angku Syekh Surau Gadang Pakandangan, seperti: Tafsir, Fiqih, Nahwu Syaraf dapat beliau pahami dengan mudah.

Melihat kemajuan yang luar biasa itu pula, oleh guru, Angku Syekh Surau Gadang, ia diperintahkan untuk pindah mengaji di Padang Gantiang, Batusangkar kepadaSyekh Padang Gantiang. Kebijaksanaanitu diambilolehSyekhSurau Gadang Pakandangan, karena ia berharap agar ilmu yang dikuasasi oleh "Karaping" dapat bertambah, karena, seluruh ilmu yang dikuasai oleh Angku Syekh Surau Gadang telah dikuasai pula oleh Angku Paseban. Dipilihnya Syekh Padang Gantiang, karena Syekh Padang Gantiang itu sendiri tak lain adalah guru dari Syekh Gadang Pakandangan.

Di Padang Ganting, Karaping selain belajar menjadi murid, ia juga diizinkan mengajar dan diberi murid sebanyak enam puluh orang. Setiap harinya, di siang hari ia mengajar murid-muridnya dan pada sore harinya ia belajar kepada Angku Syekh Padang Ganting. Oleh Syekh Padang Gantiang, Karaping diajarkan ilmu Nahwu, Syaraf, Tafsir, Fiqih, Mantiq Ma'ana, Usul Tauhid. Tak lama kemudian, karena telah berhasil menguasai ilmu-ilmu yang diberikan, Angku Syekh Padang Ganting menerima bai'at dan talakin zikir Karaping, sehingga mulai saat itu resmilah ia menjadi khalifah Angku Syekh Padang Ganting dan menerima tarekat Syattari. Oleh orang kampungnya sendiri Karaping terkenal dengan julukan Syekh ahli Tafsir dan ahli tarekat Syattari.

Masih di Padang Gantiang, suatu hari, datang seorang dari Nagari Sungai Abang meminta Syekh Padang Gantiang untuk mengajar di Sungai Abang, oleh Syekh Padang Gantiang maka diperintahnyalah Karaping menerima permintaan orang tersebut untuk mengajar di sana. Dan esoknya, Karaping berangkat ke Sungai Abang dan mengajar di sana. Di Sungai Abang, ia mendapatkan murid yang tidak sedikit, sebagian besar murid-muridnya itu berasal dari daerah rantau Pariaman, dan ada juga yang berasal dari daerah darek. Tak beberapa lama kemudian, timbul rasa rindu dalam diri Karaping terhadap kampung halaman yang telah lama ditinggalkannya. Selanjutnya, ia memutuskan untuk pulang ke kampungnya di Nagari Koto Tangah dan mengajar di sana. Di Koto Tangah, Karaping mendirikan sebuah surau di atas tanah bekas Rumah Tahanan (penjara = Paseban), itulah awal julukan "Paseban" diberikan padanya.

Di Koto Tangah inilah Syekh Paseban memperoleh banyak pengalaman. Ia 
pernah dijebloskan ke dalam penjara oleh seorang Camat yang baru saja bertugas di Nagari Koto Tangah. Kesalahan beliau pada waktu itu adalah tidak pernah membayar rodi, padahal menurut peraturan yang ada, ulama dibebaskan akan rodi. Namun, sepertinya hal ini memang sengaja dilakukan oleh sang Camat, alasannya adalah untuk menutupi rasa malu yang terimanya karena Syekh Paseban mempermalukan gurunya Inyiak Rasul dan berarti juga mempermalukan dia. Memang pada waktu itu, gelombang reformasi keislaman di Mekkah juga dapat di rasakan di Koto Padang. Inyiak Rasul yang merupakan ulama dari golongan muda, mengkritik kebiasaan mancaliak bulan yang dilakukan oleh kelompok Islam konservatif untuk mengetahui datang dan perginya bulan Ramadhan. Menurut Inyiak Rasul, kebiasaan itu sangat berbahaya dan lagi di zaman sekarang, telah tercipta ukuran waktu yang akurat yaitu "kalender" sehingga telah dapat diketahui kapan datang dan perginya bulan Ramadhan. Namun, pendapat Inyiak Rasul tersebut di tolak dengan halus oleh Syekh Paseban. Ia -Syekh Paseban- mengatakan bahwa ia juga ingin sekali mengikuti jalan yang mudah itu, ia pun mengakui bahwa mancaliak bulan sangat berbahaya, namun sebelum ia ikuti jalan yang mudah itu, ia terlebih dahulu meminta kepada Inyiak Rasul untuk membunyikan hadits Rasulullah SAW yang menyebutkan bahwa untuk memastikan kapan masuk dan kapan habisnya Ramadhan cukup dengan hanya melihat kalender tidak melihat bulan. Mendengar tanggapan Syekh Paseban tersebut, terdiamlah Inyiak Rasul karena memang tidak ada hadits yang menyebutkan hal itu. Dan akhirnya seluruh penduduk mengikut Syekh Paseban.

Lama kelamaan, pengikut Syekh Paseban pun bertambah banyak, bukan saja orang dari Nagari Koto Tangah melainkan juga dari berbagai pelosok Nagari di Minangkabau, seperti Pauah, Solok, Batu Sangkar, Bukittinggi, Padang Panjang, Sungai Abang dan lainnya. Popularitas ia sebagai seorang ulama pun bertambah, bahkan ada pameo pada waktu itu untuk "para ulama baru" apabila mereka belum pernah berguru kepada Syekh Paseban maka diragukan kompetensinya sebagai seorang ulama. Ia bahkan pernah dimintai pertolongan oleh Komandan tentara Belanda untuk membantu Belanda mengentikan aktivitas pergolakan yang dimotori oleh PKI di daerahnya, Koto Tangah.

/....Maka pada suatu pagi sedang beliau Syekh Paseban sedang mengajar, datanglah serombongan tentara Belanda yang dikepalai oleh "Uyus" itulah nama pangkat Komandannya. Hampir tiba mereka dituturan surau, dikhabarkan orang kepada beliau bahwa tentara Belanda akan naik ke atas surau. Maka beliau lekas keluar. Tiba di muka jenjang Uyus akan menginjak anak jenjang "tunggu! Tunggu di situ!" Kata beliau. Uyus berdiri di muka jenjang. "Apa khabar?" Kata beliau. Menjawab Uyus "kedatangan kami minta bantuan pendeta, menolong mengamankan keadaan ini kalau tidak kami akan melakukan tindakan keras." Berkata Syekh Paseban "nanti malam saya urus." Malamnya pergilah beliau ke lapau. Di halaman Surau Gadang Koto Panjang sedang rami. Maka beliau berkata waktu itu "kalau kalian ingin Negeri aman, pulang-pulangkanlah surat merah itu kalau tidak lepas tanggung jawab aku. Tentara Belanda akan bertindak keras." Sudah berkata beliau kembali ke surau. Maka beresok harinya dipulang-pulangkan oranglah Surat Merah itu. Maka pemimpin Komunis sesudah itu banyak yang terbunuh dan tertangkap seperti si Pati dan si Lanjai.../ (Ibid: 32). 
Sebagai seorang ulama, Syekh Paseban tentu memiliki keinginan untuk menunaikan ibadah haji, untuk menyempurnakan rukun Islamnya. Akhirnya niat tersebut dikabulkan oleh Allah SWT, ia pun berangkat menunaikan ibadah haji. Sebelum Syekh Paseban berangkat ke Negeri Mekkah, ia mengangkat beberapa orang muridnya untuk dijadikannya khalifahnya. Maka, bertepatan tanggal 27 Rajab 1356 Hijrah (1937 Masehi) mengangkat tiga orang khalifah yakni: Angku Fakih Lutan dari Koto Tangah, Angku Inyik Adam juga dari Koto Tangah, dan Angku Haji Abdul Majid dari Paseban. Sedangkan Haji Imam Maulana Abdul Manaf Amin Al-Khatib (Penulis naskah SP) tidak sempat diangkat sebagai khalifah, karena pada waktu syekh Paseban hendak berangkat haji ke Mekkah, umur Imam Maulana masih sangat kecil, yakni 12 tahun.

/...Orang yang akan menjadi khalifah beliau, Syekh Paseban adalah bertiga orang (Pertama) Pakih Lutan. (Kedua) Pakih Adam. (Ketiga) Haji Abdul Majid Pauh Kambar.../ (Ibid: 77).

Angku Fakih Lutan dan Angku Inyiak Adam ditugaskan dalam urusan adat, sedangkan Angku Haji Abdul Majid. Selain keempat orang tersebut, Syekh Paseban juga menunjuk beberapa orang sebagai penasehat. Mereka antara lain, Angku Qadi Talang dari Solok, Angku Syekh Datuk dari Lumindai, Angku Surau Gadang dari Tanjung Medan Ulakan, Angku Ibrahim dari Mudik Padang.

Sebelum keberangkatannya,SyekhPaseban menitipkan beberapa pesankepada mereka (para khalifah dan penasehat), pertama, bahwa sekiranya ia meninggal di Mekkah, maka kuburkanlah ia di Mekkah, karena ia tidak mau mayatnya dikuburkan di kampungnya, karena apabila ia dikuburkan di kampungnya, maka mungkin kuburnya akan diziarahi orang juga.

/...Kalau ada sesuai dengan qhadar Tuhan, tinggal saya di Mekkah hendaknya. Kalau saya berbalik pulang akan berdosa pula orang Koto Tangah, sebab kalau saya kembali pulang tentu kubur saya diziarahi [pulang] pula. Maka dikata orang yang anti kuno, orang ziarah aku itu orang menyembah kubur.../ (Ibid: 88).

Kedua, ia pun meminta kepada keempat khalifahnya untuk selalu menjaga kitab-kitab yang ada di suraunya, ia tidak merestui apabila kitab-kitab itu keluar dari suraunya. Barang siapa yang memerlukan kitab-kitab itu, ia izinkan untuk menyalinnya, namun jangan sekali-kali membawa keluar kitab-kitabnya itu dari suraunya.

Tujuan Syekh Paseban ke tanah suci yang lainnya adalah selain memang ingin menunaikan ibadah haji, ia ingin sekali "membuka kaji" di Mekkah, untuk itu di antara kitab-kitabnya, ada beberapa kitab yang sengaja dibawanya ke Mekkah. Di Mekkah, ternyata niat untuk "membuka kaji" tidak kesampaian. Kaum reformis Mekkah mengeluarkan larangan terhadap setiap bentuk ajaran-ajaran Islam kuno untuk dikembangkan. Bahkan kitab-kitab ajaran Islam kuno itupun telah dibakar dan para ulamanya yang tidak mau bekerja sama dengan kaum Islam moderat di 
bunuh. Bukan itu saja, karena faktor usia membuat ia tidak dapat secara penuh melakukan ibadah haji. Di asrama, Syekh Paseban sering jatuh sakit, sehingga ia harus dirawat oleh tim kesehatan (mantri) secara intensif. Akhirnya Syekh Paseban meninggal dunia. Sesuai dengan permintaannya, maka oleh sanak keluarganya jasadnya dikuburkan di Mekkah.

\section{Daftar Kepustakaan}

Amran, Rusli. 1985. Sumatera Barat Plakat Panjang. Jakarta: Sinar Harapan.

Amir, Adriyetti. 2001. Sejarah Ringkas Aulia Allah Asshalihin Syeh Burhanuddin Ulakan:

Pengantar dan Transliterasi. Padang: Puitika FSUA. . 2002. "Skriptorium Minangkabau" (makalah). Padang: Simposium

Internasional Masyarakat Pernaskahan Nusantara VI-Universitas Andalas.

Ali, K. Prof. 2003. Sejarah Islam: Tarikh Pramodern. Jakarta: PT. RajawaliGrafindo Persada.

Al-Khatib. 2001. Inilah Sekajarah Ringkas Syekh Paseban Assyattari Rahimahullah Ta'ala Anhu. Batang Kabung, Tabing-Padang.

Azra, Azyumardi. Prof. DR. 2004. Jaringan Ulama: Timur Tengah dan Kepulauan

Nusantara Abad XVII dan XVIII. Bandung: Mizan. . 2001. "Antara Kesetiaan dan Perbenturan: Nasionalisme, Etnisitas, dan

Agama di Indonesia dan Malaysia," dalam KamaruzzamanBustamam-Ahmad, Islam

Historis: Dinamika Studi Islam di Indonesia. Yogyakarta: Galang Pers.

Fathurahman, Oman. 2001. "Naskah dan Rekonstruksi Islam Lokal: Telaah Atas Kitab Ithaf Al-

Zaki bi Sharh Al-Tuhfah Al-MursalahIla Ruh Al-Nabi" (makalah). Padang: Simposium Manassa V. 2003. Tarekat Syatariyah Di Dunia Melayu-Indonesia: Kajian Atas

Dinamika dan Perkembangannya Melalui Naskah-Naskah di Sumatera Barat.

(Disertasi). Jakarta: Universitas Indonesia.

Hamka. Prof. 1982. Ayahku: Riwayat Hidup DR. Abdul Karim Amrullah dan Perjuangan

Kaum Agama di Sumatera. Jakarta: UMMINDA. . 1950. Sejarah Islam di Sumatra. Medan: Pustaka Nasional.

Navis, A.A. 1980. "Alur Kebudayaan dalam Tingkah Laku Gerakan Politik di Minangkabau"

(makalah). Bukittinggi: Seminar Internasional Kebudayaan, Kesusastraan dan

Kemasyarakatan Minangkabau.

Suminto, H.Aqib. 1986. Politik Islam Hindia Belanda. Jakarta: LP3ES.

Suryadi. 2001. "Yang Pergi Dengan Dendam dan Kembali Dengan Cerita: Sekilas Tentang

Latar Belakang Sejarah dan Isi Syair Mekkah dan Madinah" (makalah). Padang: Simposium Manassa V.

.2004. Syair Sunur: Teks dan Konteks Otobiografi Seorang Ulama

Minangkabau Abad ke-19. Padang: Yayasan Citra Budaya.

Yatim, Badri, DR. M.A. 2002. Sejarah Peradaban Islam. Jakarta: PT. RajaGrafindo Persada. 